120426959

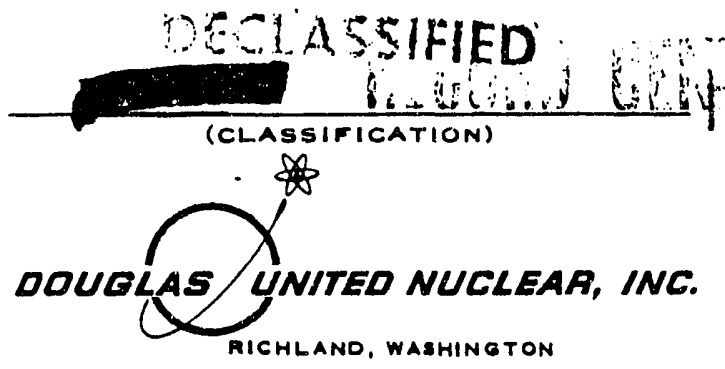

$$
\begin{aligned}
& \text { APd } \\
& \text { APR } 19 \\
& \text { OS }
\end{aligned}
$$$$
\text { DUN }--850-5
$$

vEџレ

\begin{abstract}
RESTRICTED
DATA

THIS DOCUM GONTAM DEFINED IN TH: : TE ENERGY ACT OF 1954. ITS TRM FiTLL OR TII MLOSURE OF ITS GO TNIS IN ANY MANNER TO MM PTHORIZED LRSON IS PROMIBITED.
\end{abstract}

OTHER OFFICIAL CLABSIFIED INFORMATION

THIS MATERIAL CONTAINS INFORMATION AFFECTING

THE NATIONAL DEFENGE OF THE UNITED STATES WITHIN THE MEANING OF THE ESPIONAGE LAWS, TITLE 10, U. S.C., SKCS. 793 AND 794, THE TAANSMISBION OR REVELATION OF WHICH IN ANY MANNER TO AN UNAUTHORIZED PERBON IS PROHIBITED BY LAW.

TITLE

MANUFACTURING SECTION SEMIANNUAL SUMMARY REPOF PERIOD ENDING JUNE 30,1968 .

AUTHOR

D. L. DeNeal
CIRCIISATING COPY
RECEIVED 7:O A?EA

\section{OCT 11968}

RET!IRTin Ti)

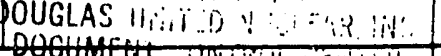

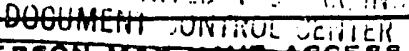

THIS DOCUMENT MUET NOT EE LEFT UNATTENDED OR WHERE AN UNAUTHORIZED PEASON MAT MAVE AREAEQR TO IT. WHEN NOT IN UEE, IT MUST EE STORED IN AN APPROVED LOCKED REPOSITORY WITHIN AN APPROVED GUARDED AREA. WHILE IT IS YOUR POBSESBION AND UNTIL YOU HAVE OETAINED A BIGNED AECEIPT FROM CLABSIFIED FILES, IT IO YOUR RESPONSIBILITY TO KEEP IT AND ITE CONTENTS WITHIN THE LIMITS OF THIS PROJECT AND FROM ANY UNAUTHORIZED PERSON. ITB TRANBMITTAL TO, AND ETORAGE AT YOUA PLACE OF RESIDENCE IS PROHIEITED. IT IS NOT TO IE DUPLICATED. IF ADDITIONAL COPIEB ARE REQUIRED, OBTAIN THEM FROM THE RELATED ISBUING FILE. ALL PERSONB IIKADING THIS DOCUMENT ARE REQUESTED TO BION IN THE SPACE PROVIDED ELLOW.

\begin{tabular}{|l|l|l|l|l|l} 
MOUTE TOI & PAYROLL NO. & LOCATION & FILEGEROUTE & SIONATURE AND DATE \\
\hline
\end{tabular}

DUN Record

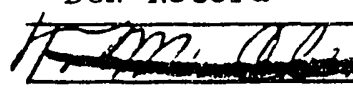

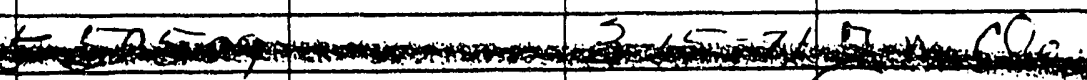
$70.76-31$

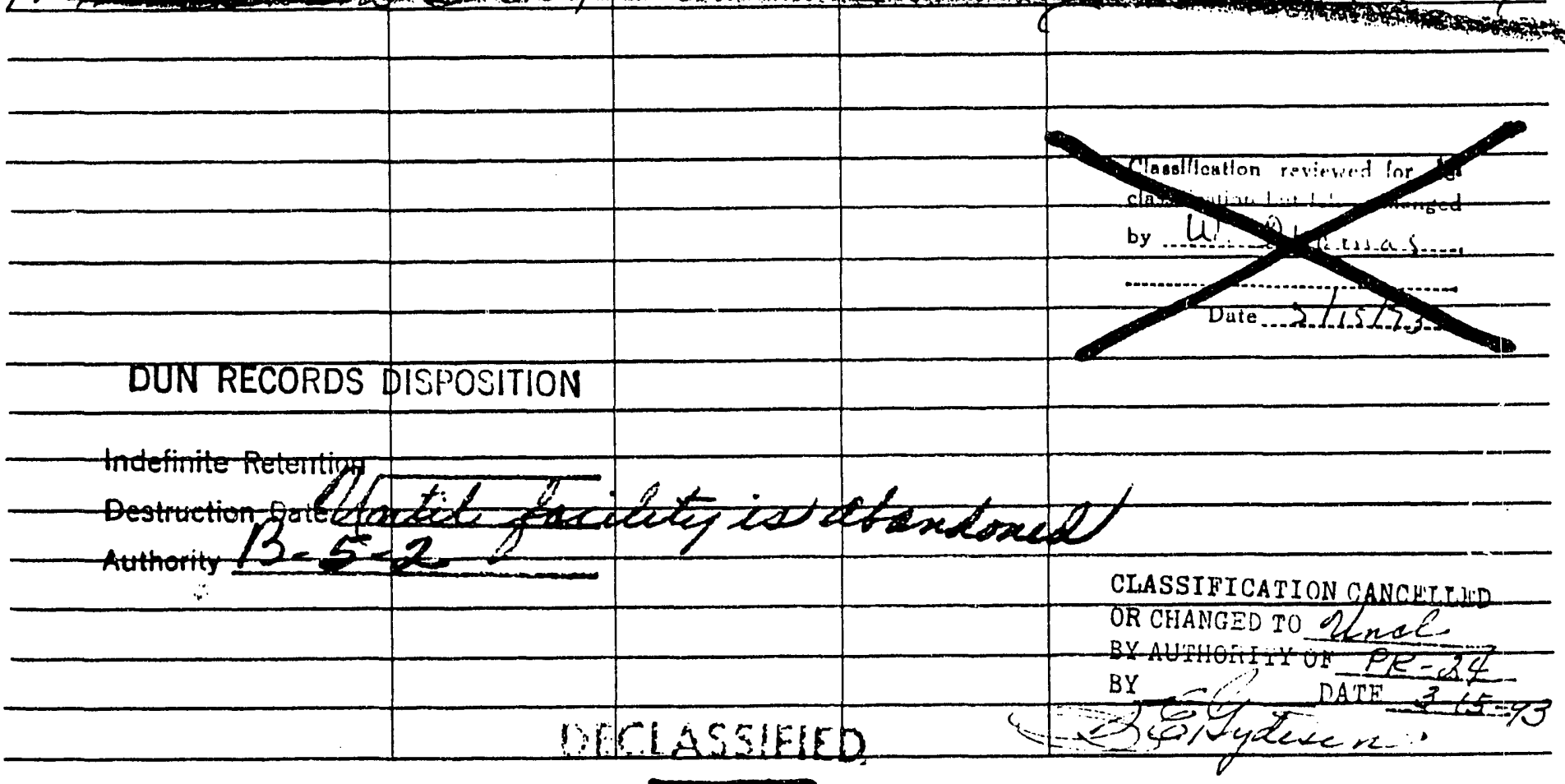



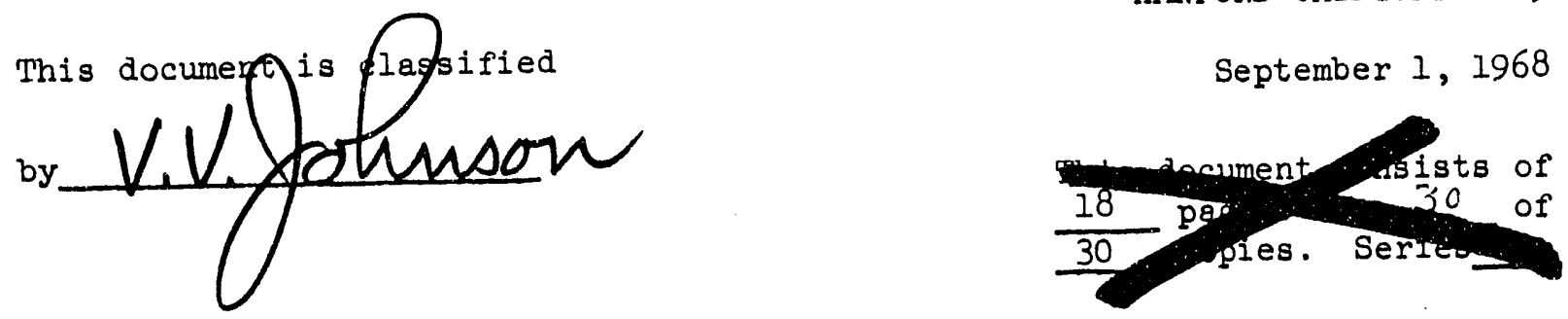

DISTRIBUTION :

1. T. W. Ambrose

2. J. J. Bombino

3. R. S. Bell

4. R. J. Bursey

5. T. M. Clement

6. D. L. DeNeal

7. R. E. Dunn

8. C. N. Gross

9. R. W. Hallet, Jr.

10. C. D. Harrington

11. R. T. Jessen

12. V. V. Johnson
13. C. W. Kuhlman

14. A. R. Maguire

15. W. M. Mathis

16. R. Nilson

17. R. L. Plum - AEC-RL

18. R. W. Reid

19. 0. C. Schroeder

20. J. T. Stringer

21. A. P. Vinther

22.-28. Extra

29. DUN File

30. DUN Record

\section{MANUFACTURING SECTION \\ SEMIANNUAL SUMMARY REPORT \\ (PERIOD ENDING JUNE 30, 1968)}

\section{By}

D. L. DeNeal

Manufacturing Section

\section{DISCLAIMER}

This report was prepared as an account of work sponsored by an agency of the United Str:es Government. Neither the United States Government nor any agency thereof, nor any of their

employees, makes any warranty, express or implied, or assumes any legal liability or responsibility for the accuracy, completeness, or usefulness of any information, apparatus, product, or process disclosed, or represents that its use would not infringe privately owned rights. Reference herein to any specific commercial product, process, or service by trade name, trademark, manufacturer, or otherwise does not necessarily constitute or imply its endorsement, recommendation, or favoring by the United States Government or any agency thereof. The views and opinions of authors expressed herein do not necessarily state or reflect those of the United States Government or any agency thereof.

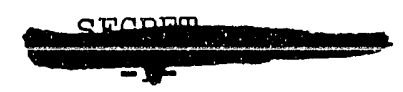




\section{MANUFACTURING SECTION \\ SEMIANNUAL SUMMARY REPORT \\ (PERIOD ENDING JUNE 30, 1968)}

\section{INTRODUCTION}

In this sixth semiannual issue, the reactor and power data are shown for the six-month period January through June, 1968 (except for B Reactor which is shown for January and February only because of deactivation at 0200 hours on February 12, 1968), together with data for the three preceding six-month periods. For comparison purpose the two years of experience will continue to be shown by dropping and adding a six-month period with each semiannual issue.

\section{STATISTICAL SUMMARY}

The most significant statistics for the two six-month periods during FY-1968, shown by individual reactors on the attached pages, are summarized on pages 3 and 4 for B-C Reactors and the $K$ Reactors ( $K E-K V_{i}$ ). Graphs showing the "Reactor Availability" for FY-1968 appear on pages 17 and 18.

Achievements and experience during the period January through June, 1968 and FY 1968 are shown below:

C Reactor experienced no fuel element failures during the period of December 27, 1967 through June 17, 1968. C Reactor also achieved a monthly production record of $70.2 \mathrm{KMWD}$ in March, 1968 exceeding their previous record by 0.1 percent. A fiscal year production record of 621.I KMWD (FY-1968) was also achieved at C exceeding their previous record by 1.2 percent.

KE Reactor achieved a fiscal year production record of 1289.7 KMWD exceeding their previous record by 0.1 percent.

\section{General}

During the January 19, 1968 outage at C Reactor a 44-tube, one-inch overbore test facility was installed.

On June 19, 1968, the KW Reactor experienced a water flow stoppage in a process tube caused by a foreign object entering the venturi. Approximately 39 days of outage were required to clear the channel and complete associated work.

Both of the K Reactors ( $K E-K W$ ) operated most of the six-month period of January-June, 1968 with five process pumps in service while "Equipment Maintenance Standard" checks were being performed on the sixth pump.

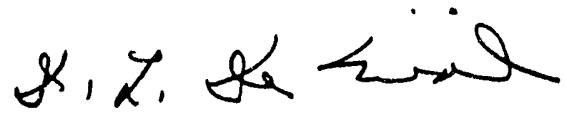

DLD:bm

D. L. DeNeal, Specialist

Production Reports \& Administration 
Production (Input)

$\frac{\text { Plutonium - KMWDs }}{\text { B-C }}$

$$
\begin{aligned}
& \text { Ks (KE \& KW) } \\
& \text { Combined }
\end{aligned}
$$

Plutonium - KgS

$\mathrm{B}-\mathrm{C}$

Ks

Combined

Uranium (U-233) - Grams

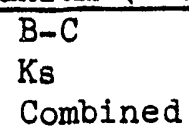

$\mathrm{Ks}$

Combined

Power Level

Maximum - Average - MW

B

C

$\mathrm{KE} \& \mathrm{KW}$

Average Operating - MW

B

C

$\mathrm{KE} \& \mathrm{KW}$

Time Operating Efficiency - (TOE \%)

$\mathrm{B}-\mathrm{C}$

$\mathrm{Ks}$

Combined

React or Outages - No.

Scheduled

Uns cheduled

Scrams

Process Tubes Replaced

$\mathrm{B}-\mathrm{C}$

Ks

Total
Jul-Dec

1967

Jan-Jun

1968

578.8

$1,303.9$

$1,882.7$

408.8

$1,042.4$

$1,451.2$

10,159

12,203

22,362

1,977

2,161

4,375

1,967

2,372

4,387

1,828

2,086

4,279

1,633

2,289

4,276

80.4

82.8

81.6

75.4

76.0

75.8
183.6

$1,549.3$

271.9

937.9

$1,209.8$

8,602

22,612

31,214

$\begin{array}{rrrrrrr}\frac{B-C}{2} & \frac{K s}{4} & \frac{\text { Total }}{6} & & \frac{\text { B-C }}{4} & \frac{\text { Ks }}{6} & \frac{\text { Total }}{10} \\ 15 & 11 & 26 & & 7 & 9 & 16 \\ 4 & 17 & 2.1 & & 4 & 16 & 20\end{array}$

57

52

11

63 
Reactor Statistical Summary - Cortd.

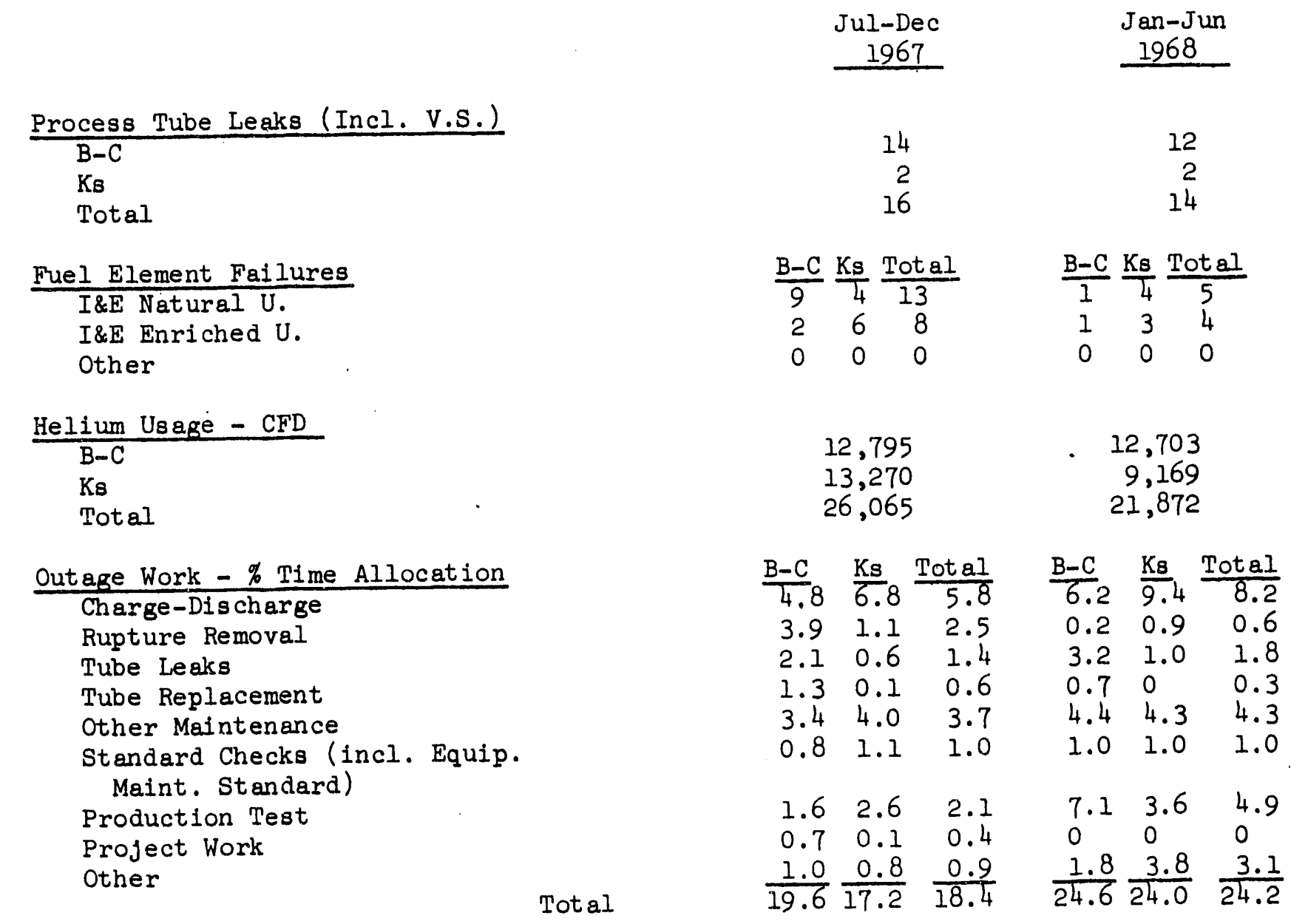




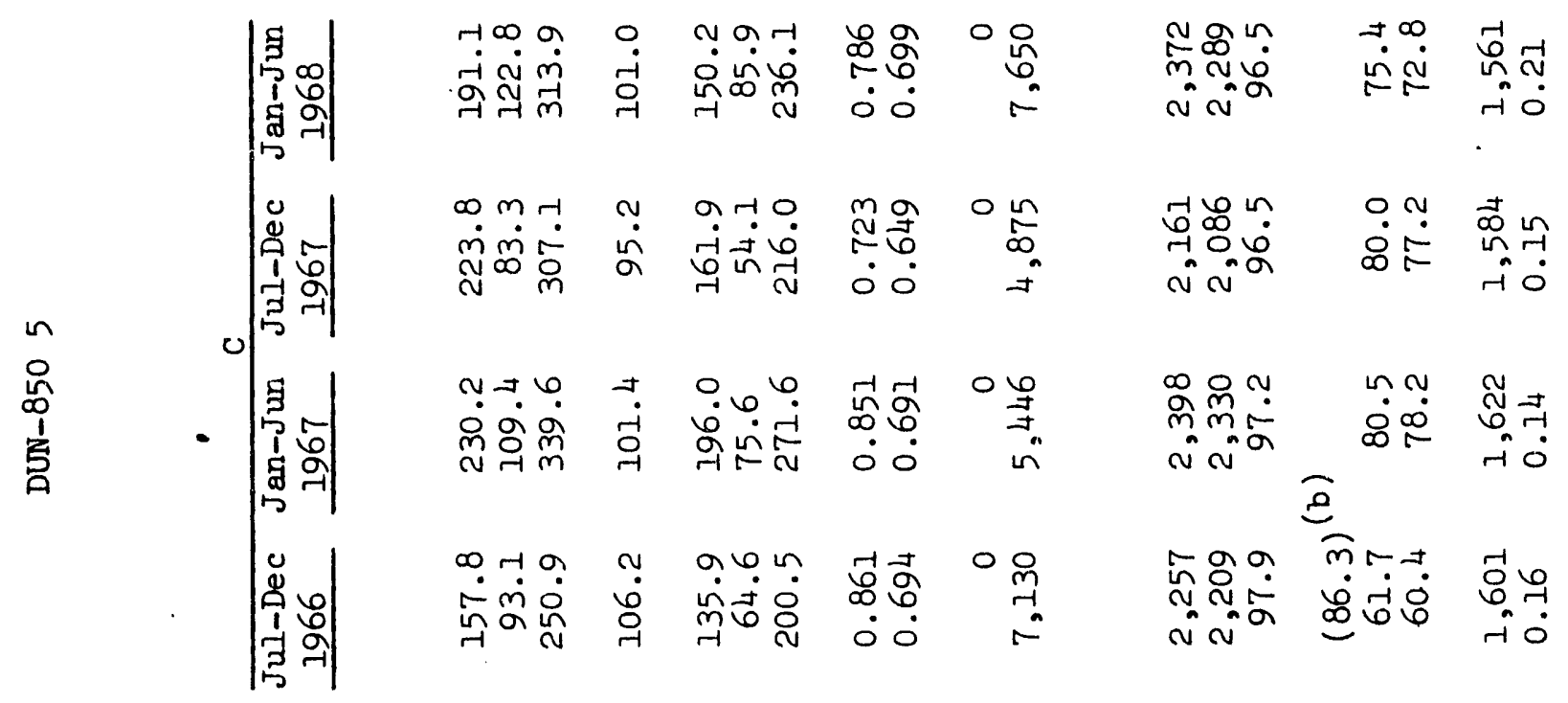

○्ञ

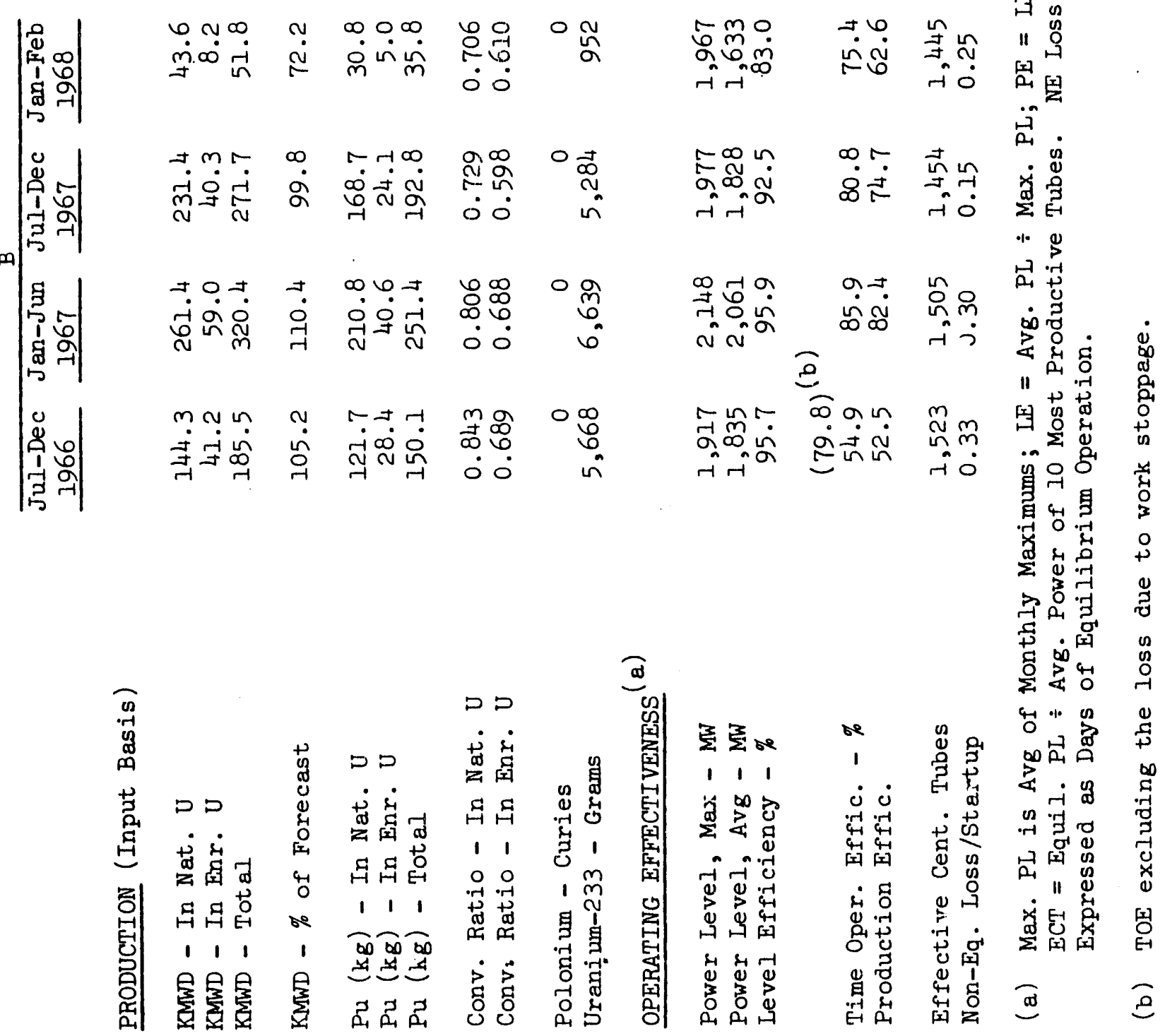




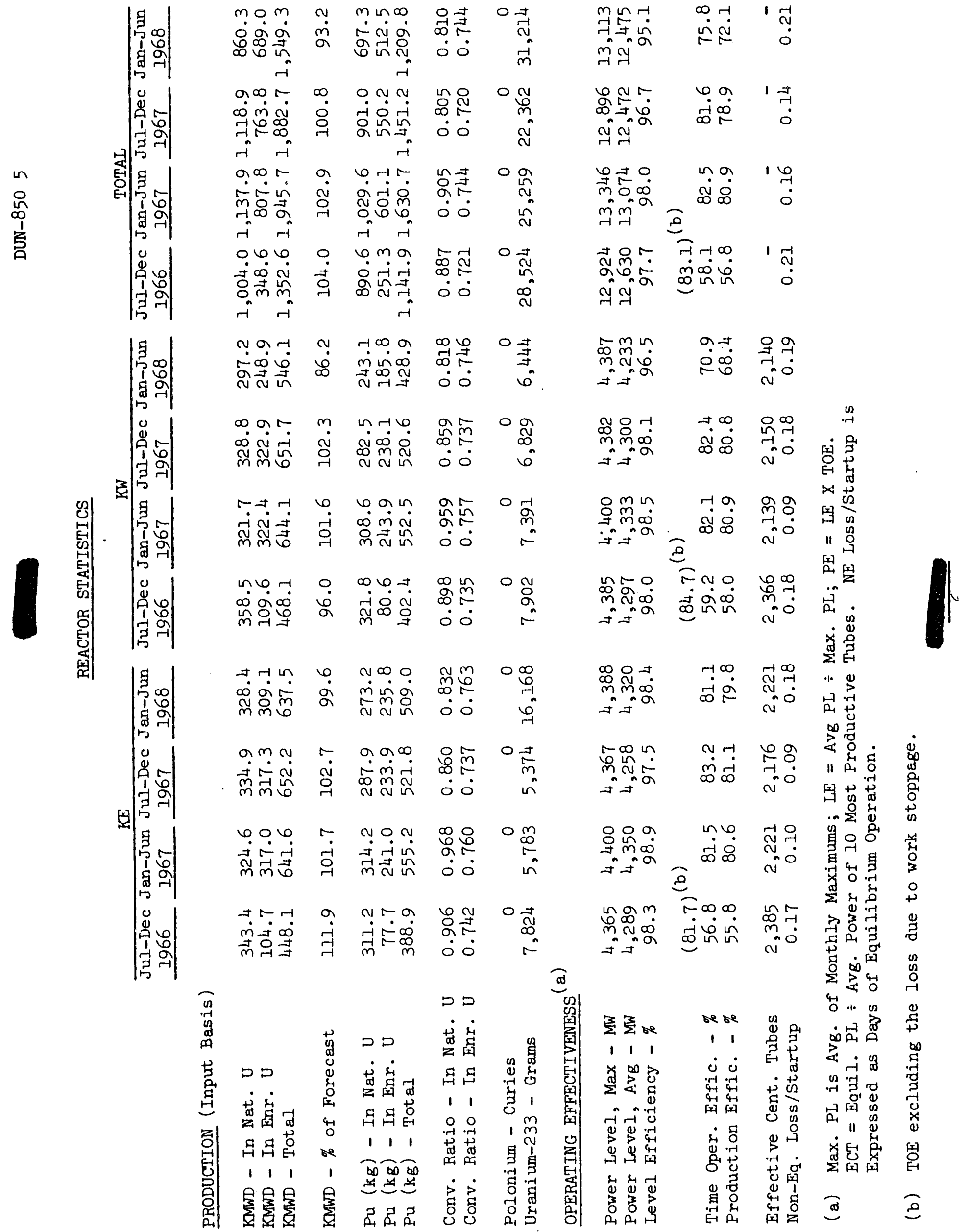



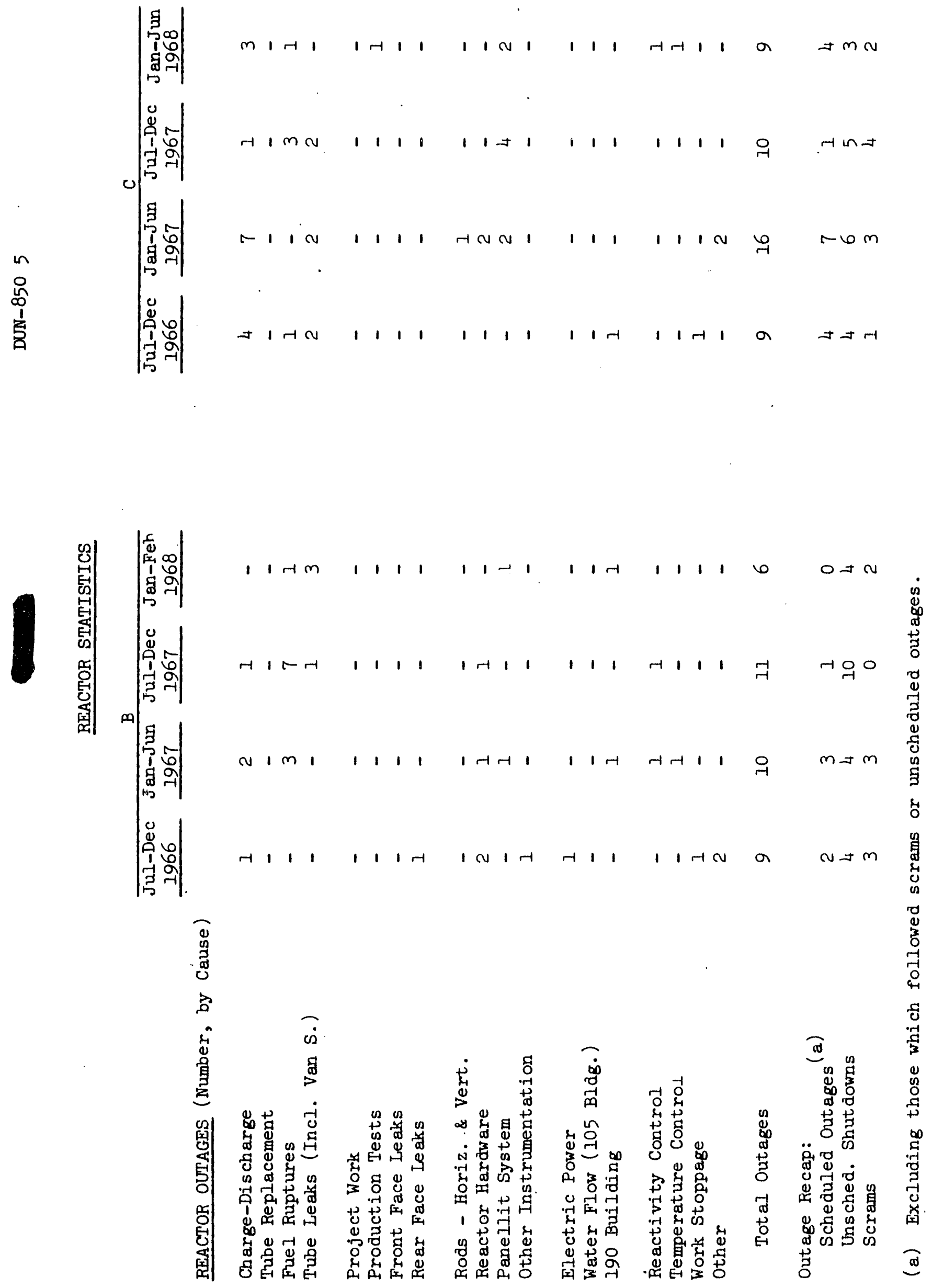

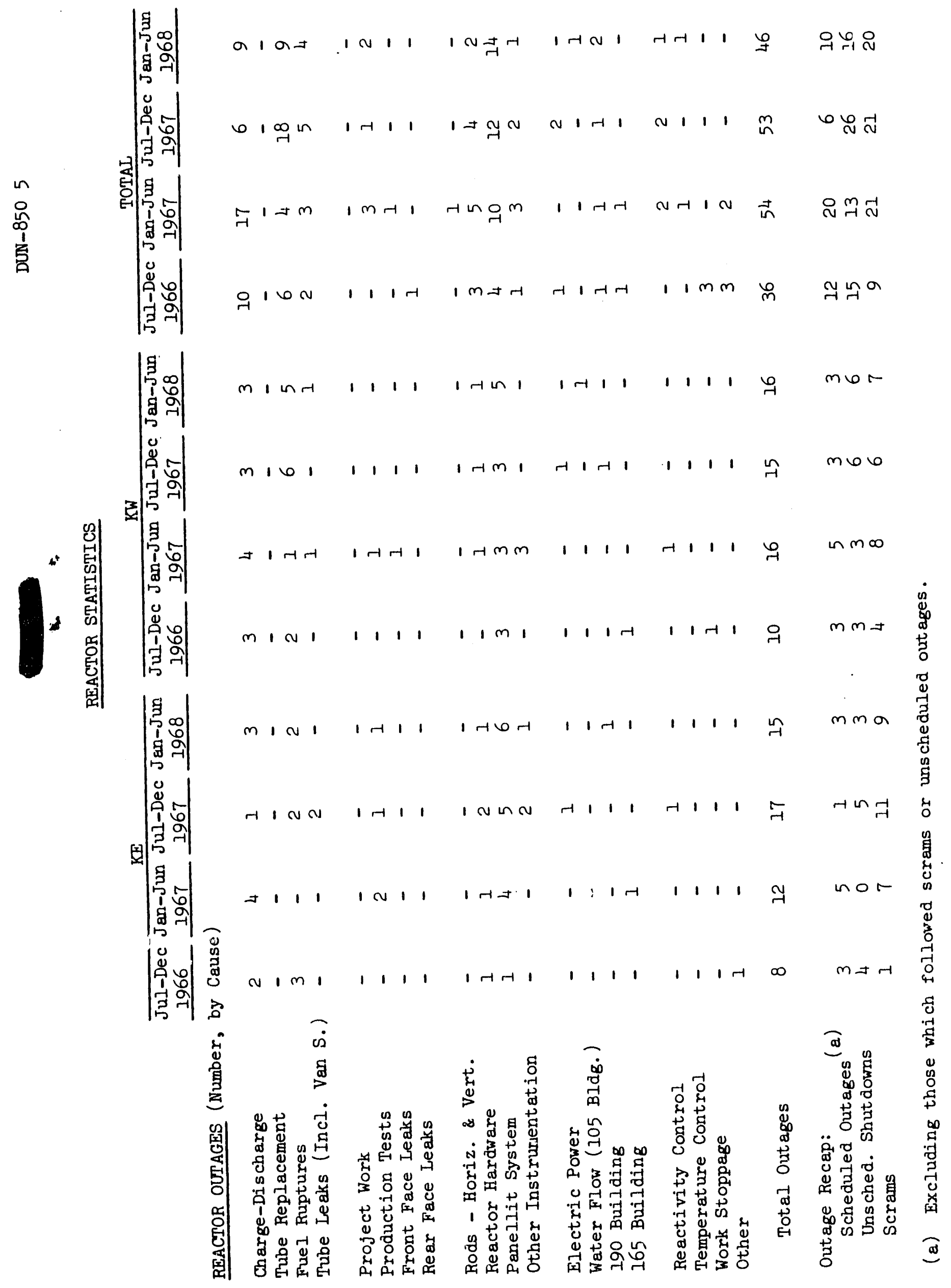

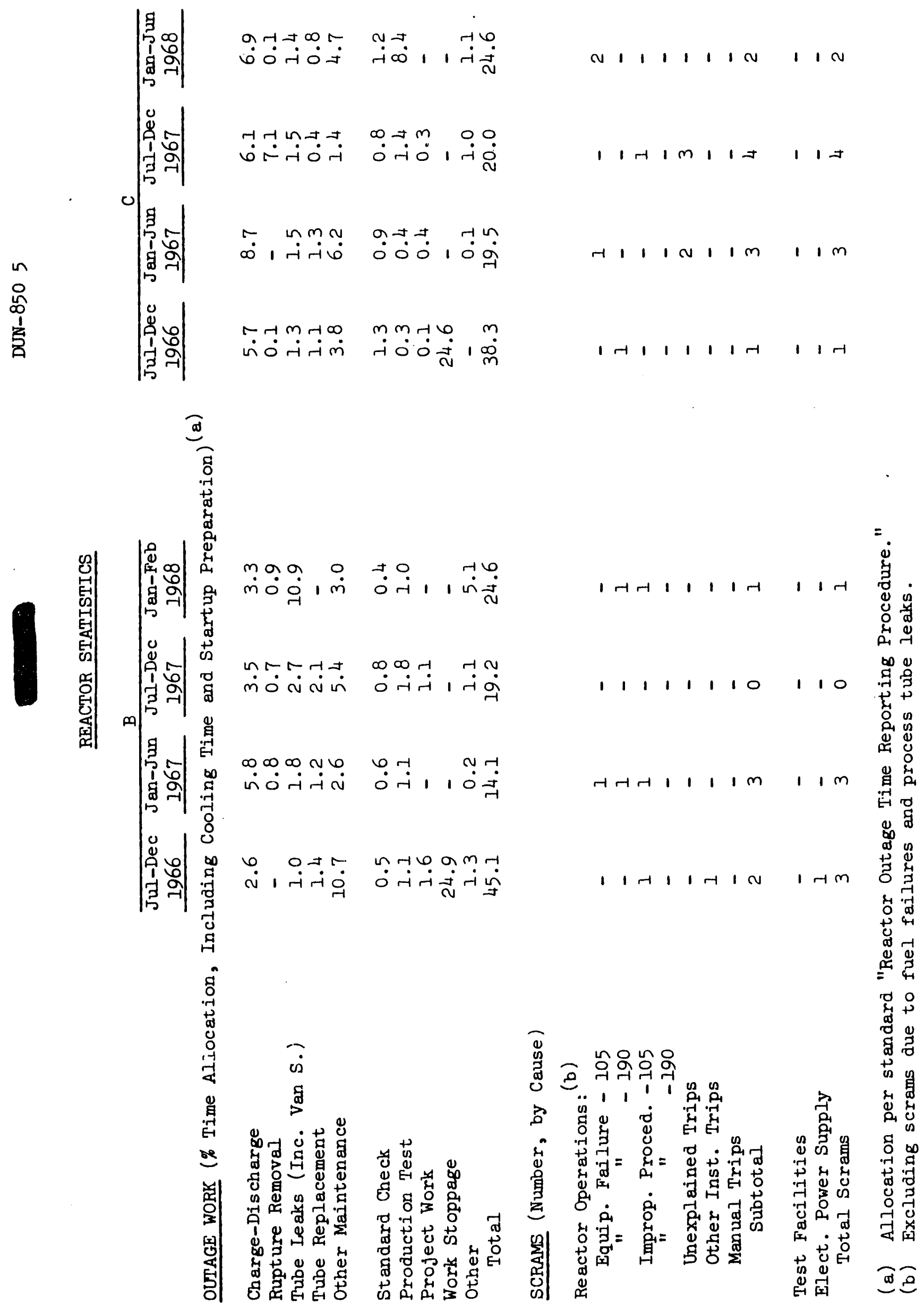


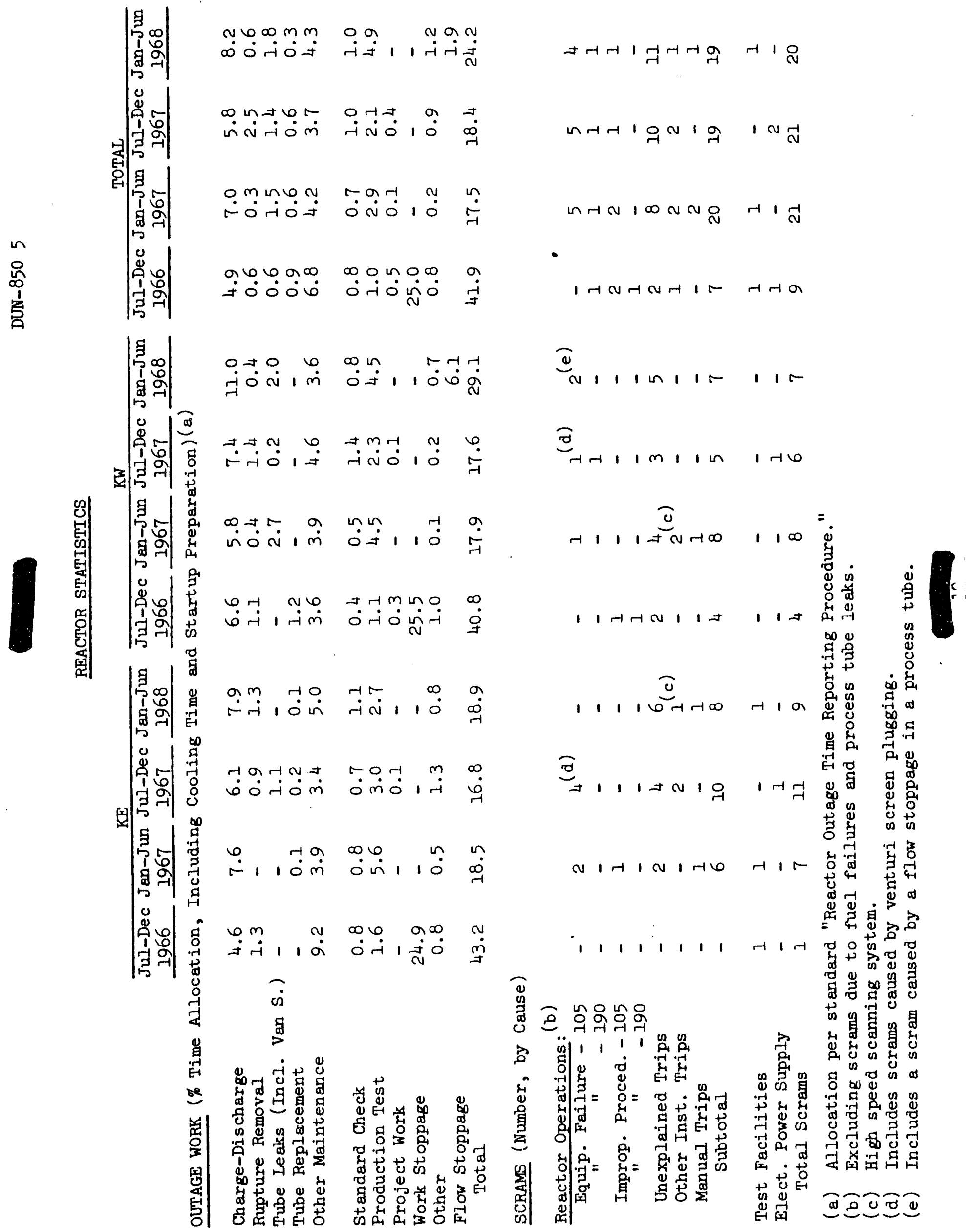




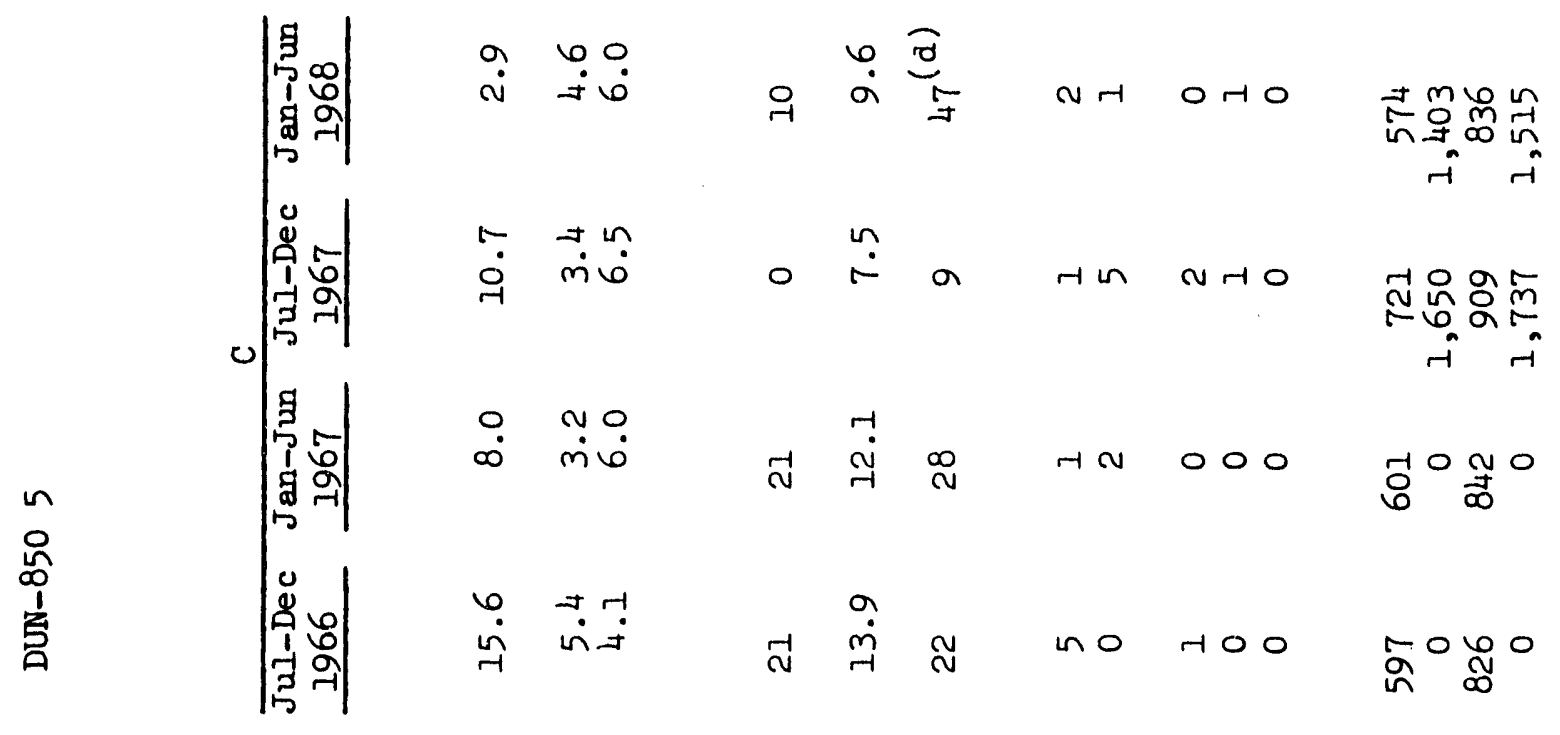
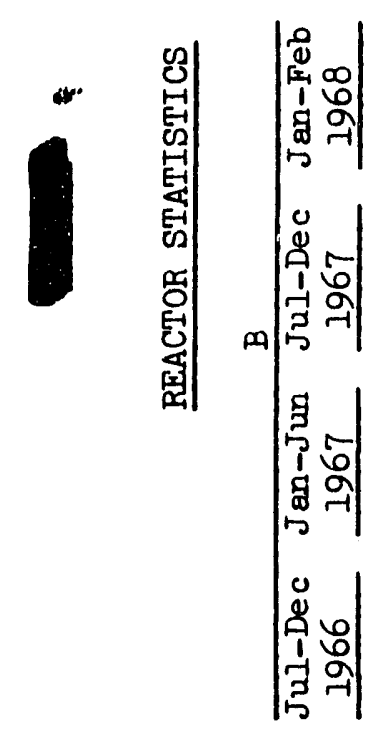

$\stackrel{m}{\stackrel{m}{N} \operatorname{li}}$

- $\ddot{v} \dot{\sim}$

$\stackrel{+}{\dot{\alpha}}$

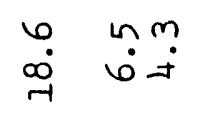

y 0 in nat hoo

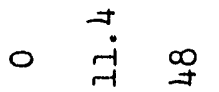

$\sim \quad \begin{aligned} & \infty \\ & \infty\end{aligned}$

m

va moo

Nm 000

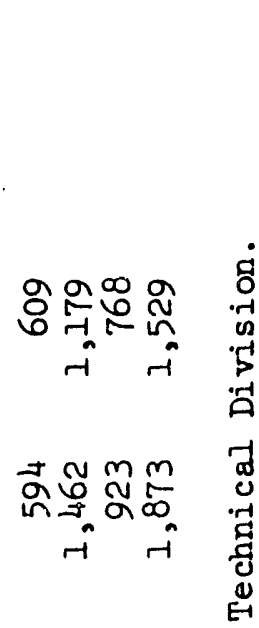

ํํํํํํํำ

त्र

이 \&

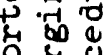

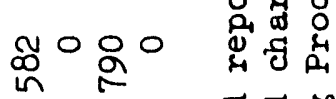

त क क

ฐ

ช 总

$\Rightarrow$ 品

$\pi_{i \rightarrow 1}^{-1}$

ठै क्षे

อิ

के

雚

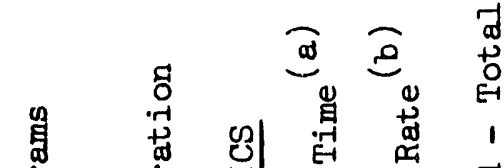

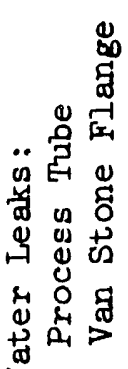

$\therefore$ o

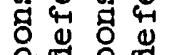

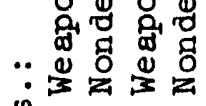

$\begin{array}{lllll}0 & 1 & 1 & 1 & 1\end{array}$

乐口ロD口

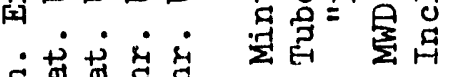

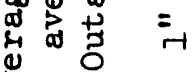

बैं क्ष

- o

iू 2

111

离象先

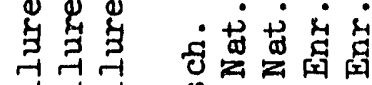

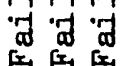

की

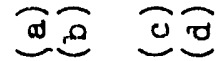




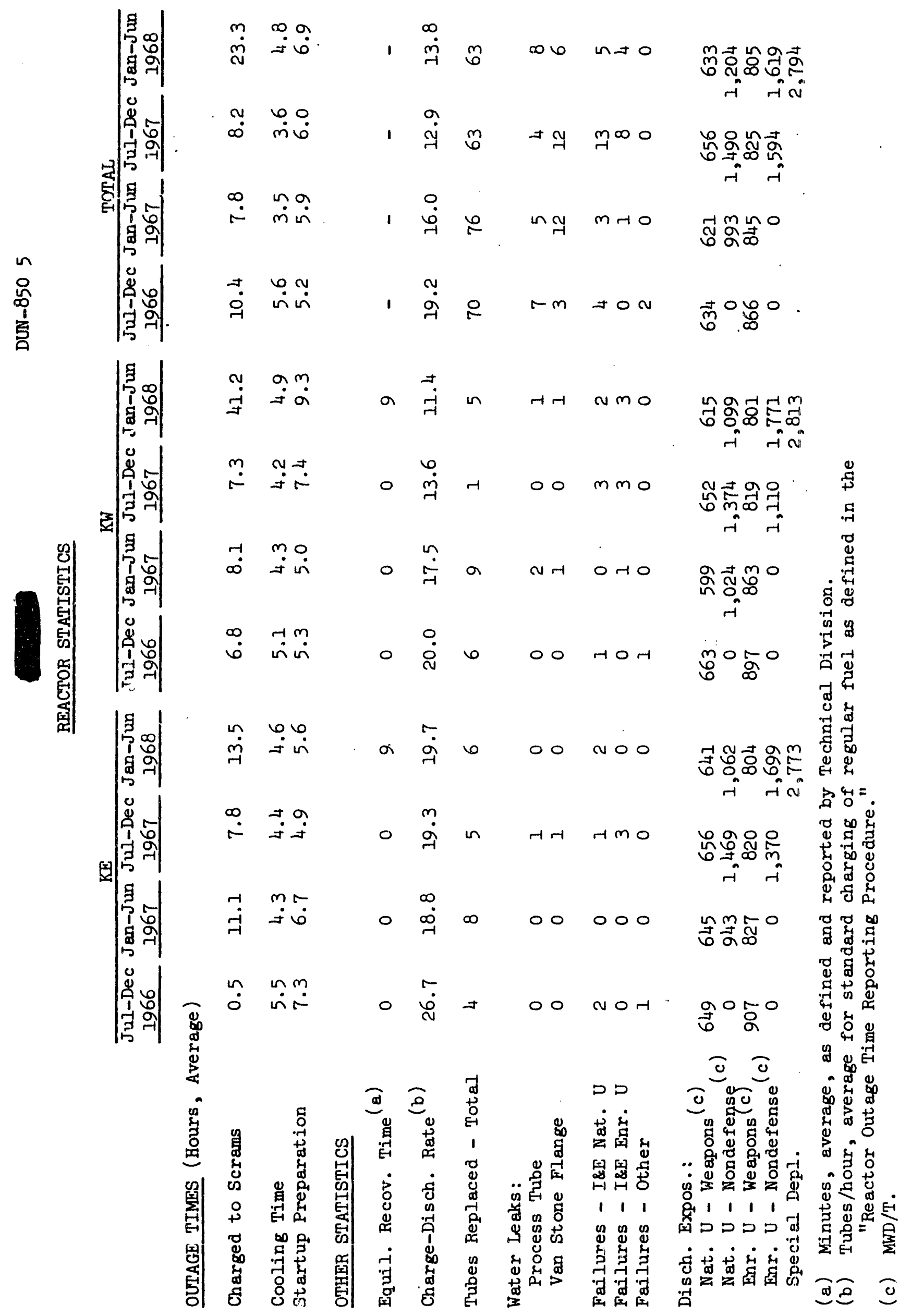



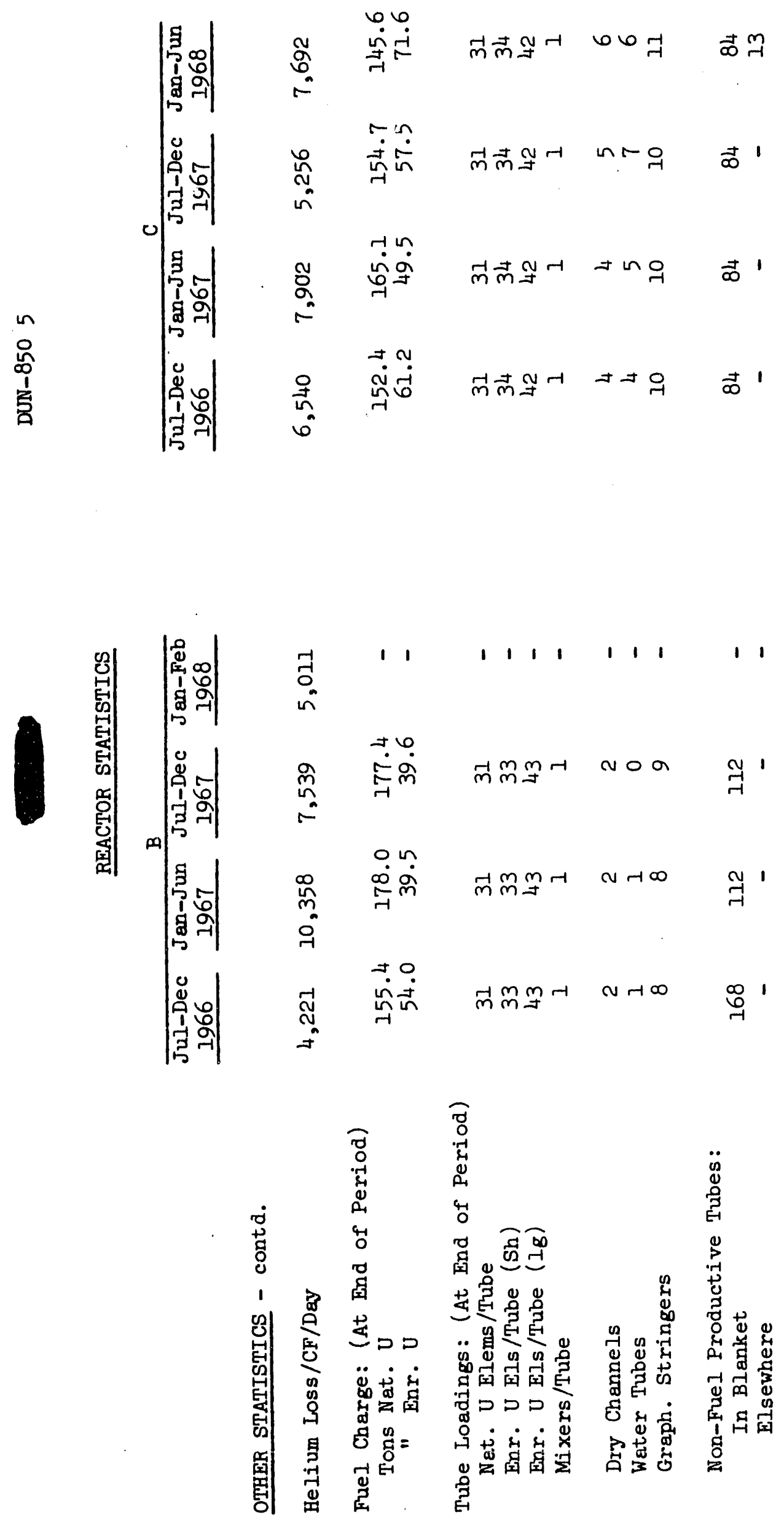


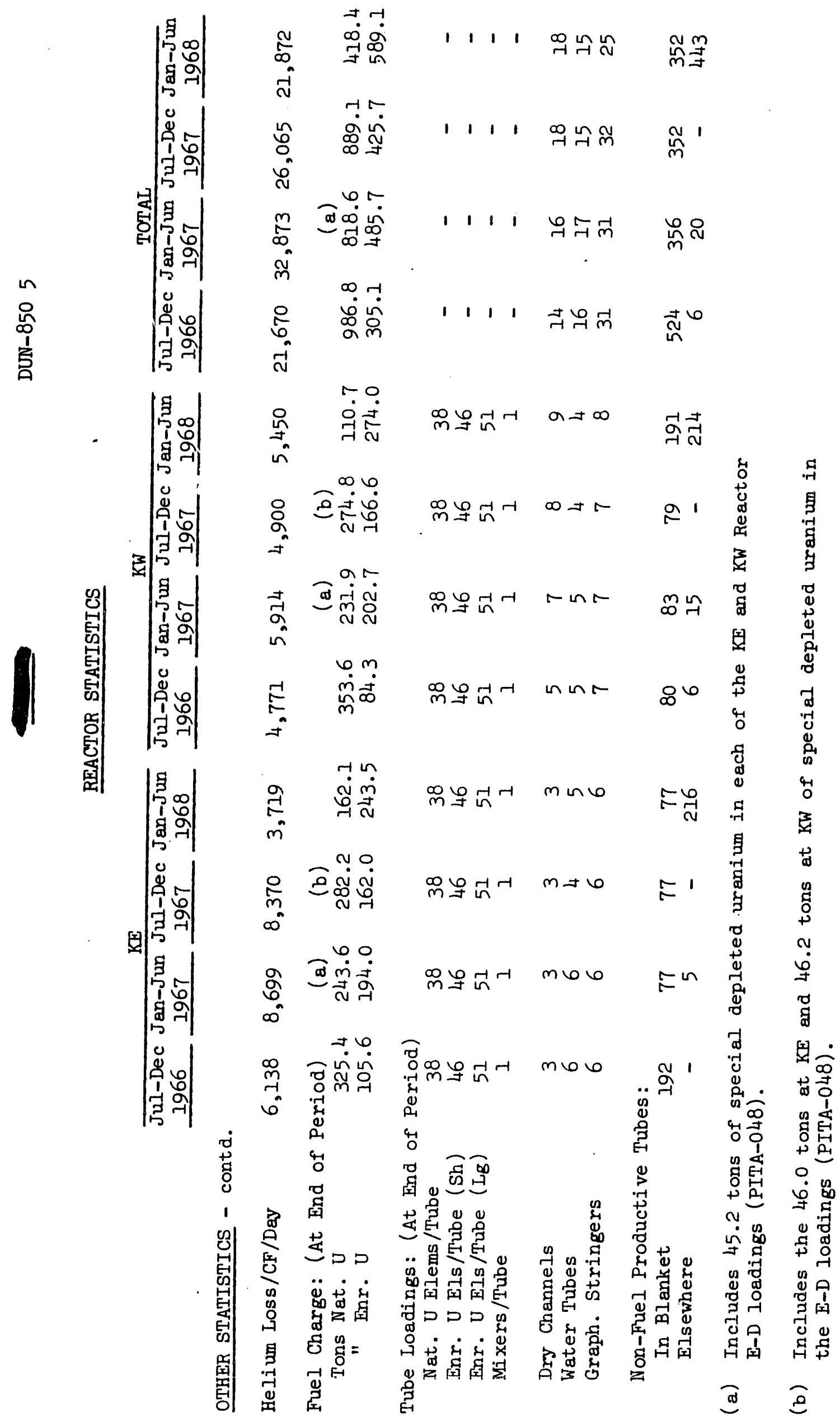



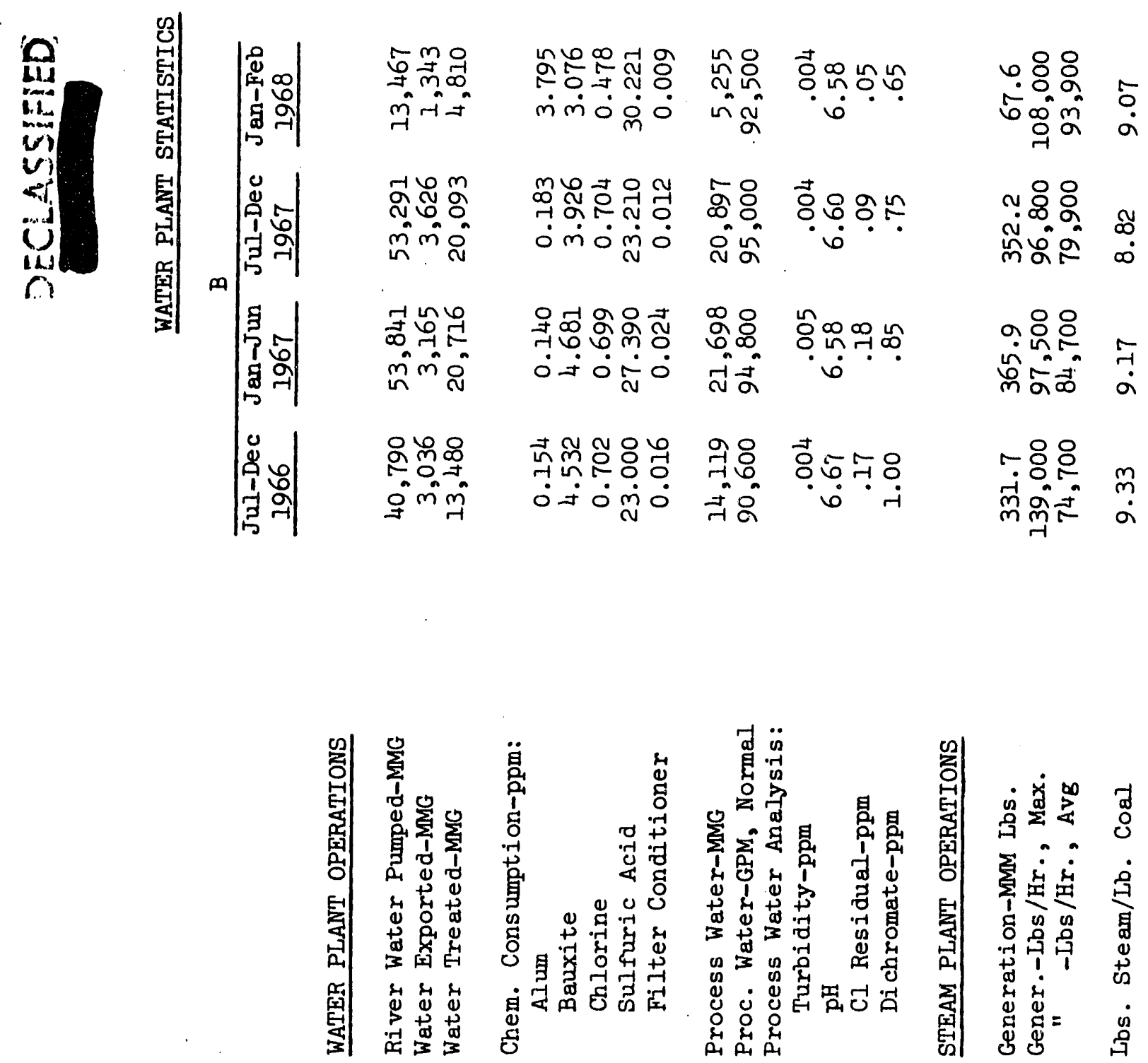

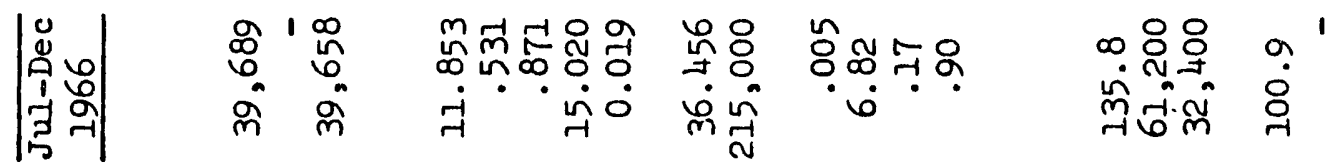
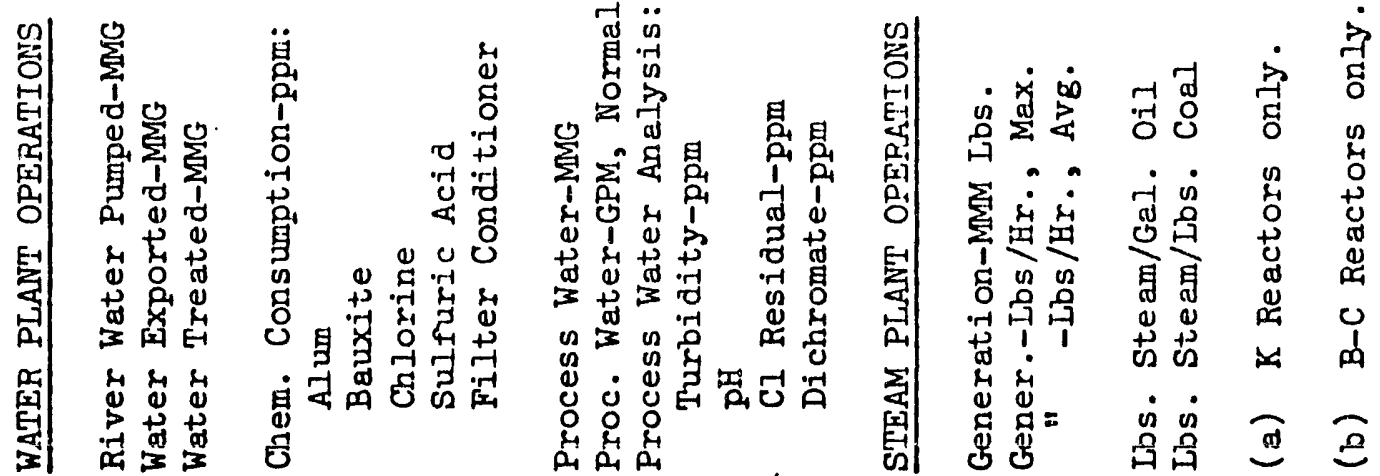


\section{REACTOR AVAILABILITY \\ (PERCENT OF TIME REACTORS OPERATED PLUS \\ SCHEDULED SHUTDOWN TIME) \\ FY 1968}

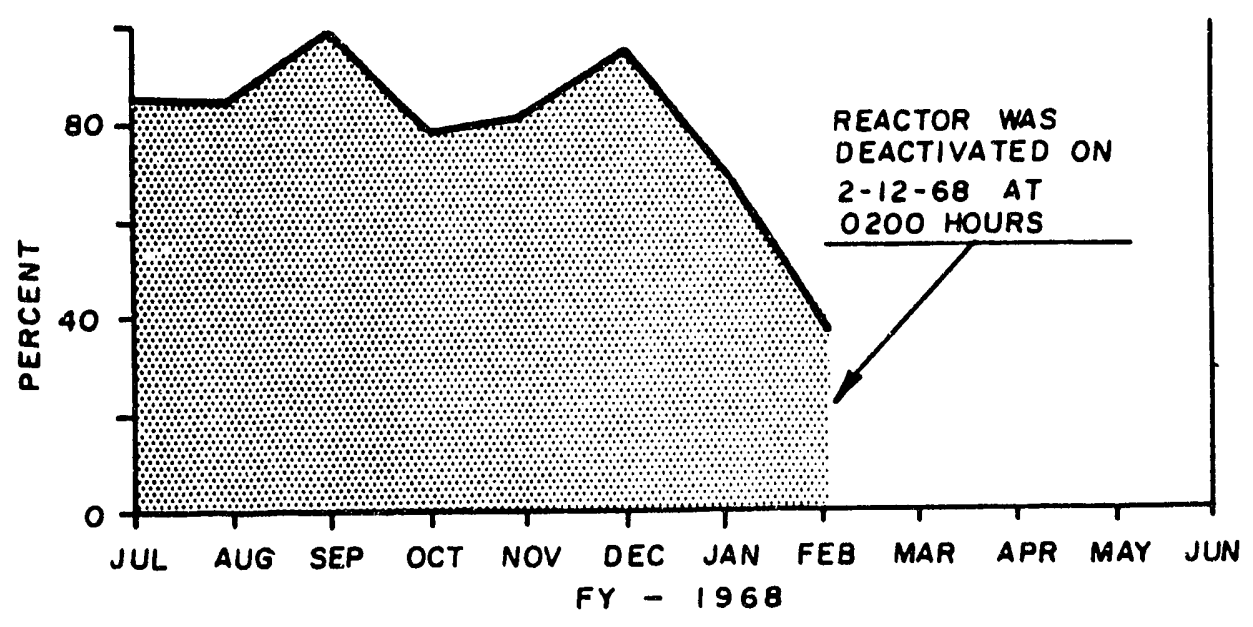

$B-$ REACTOR

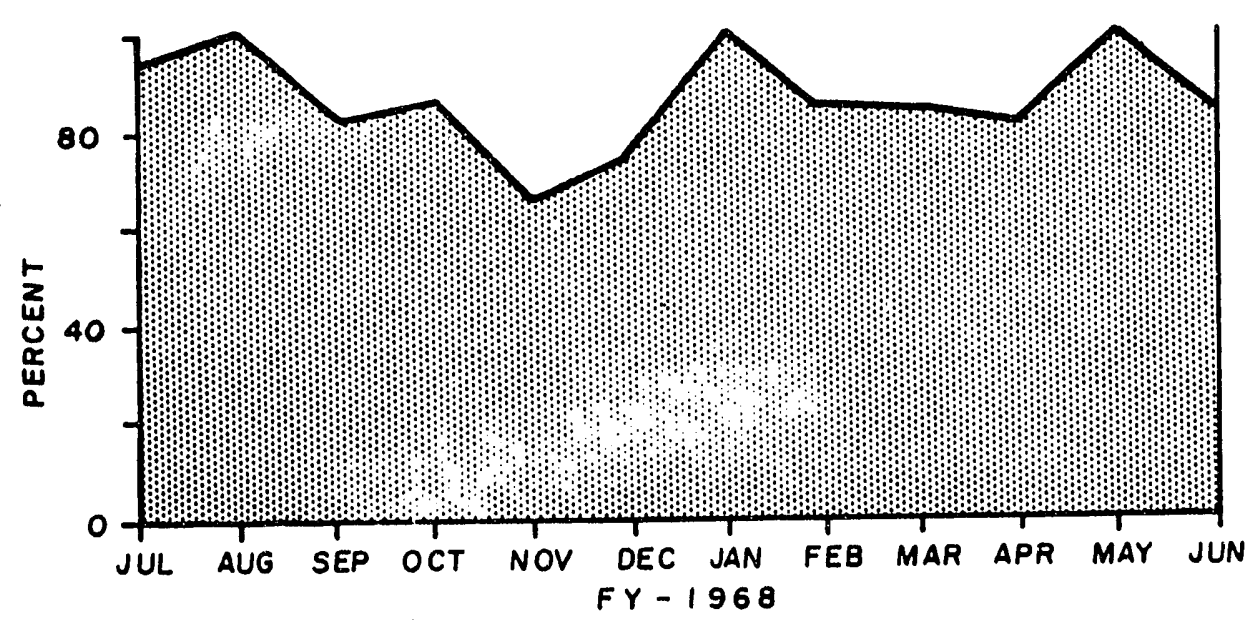

C-REACTOR

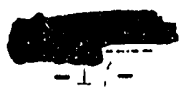



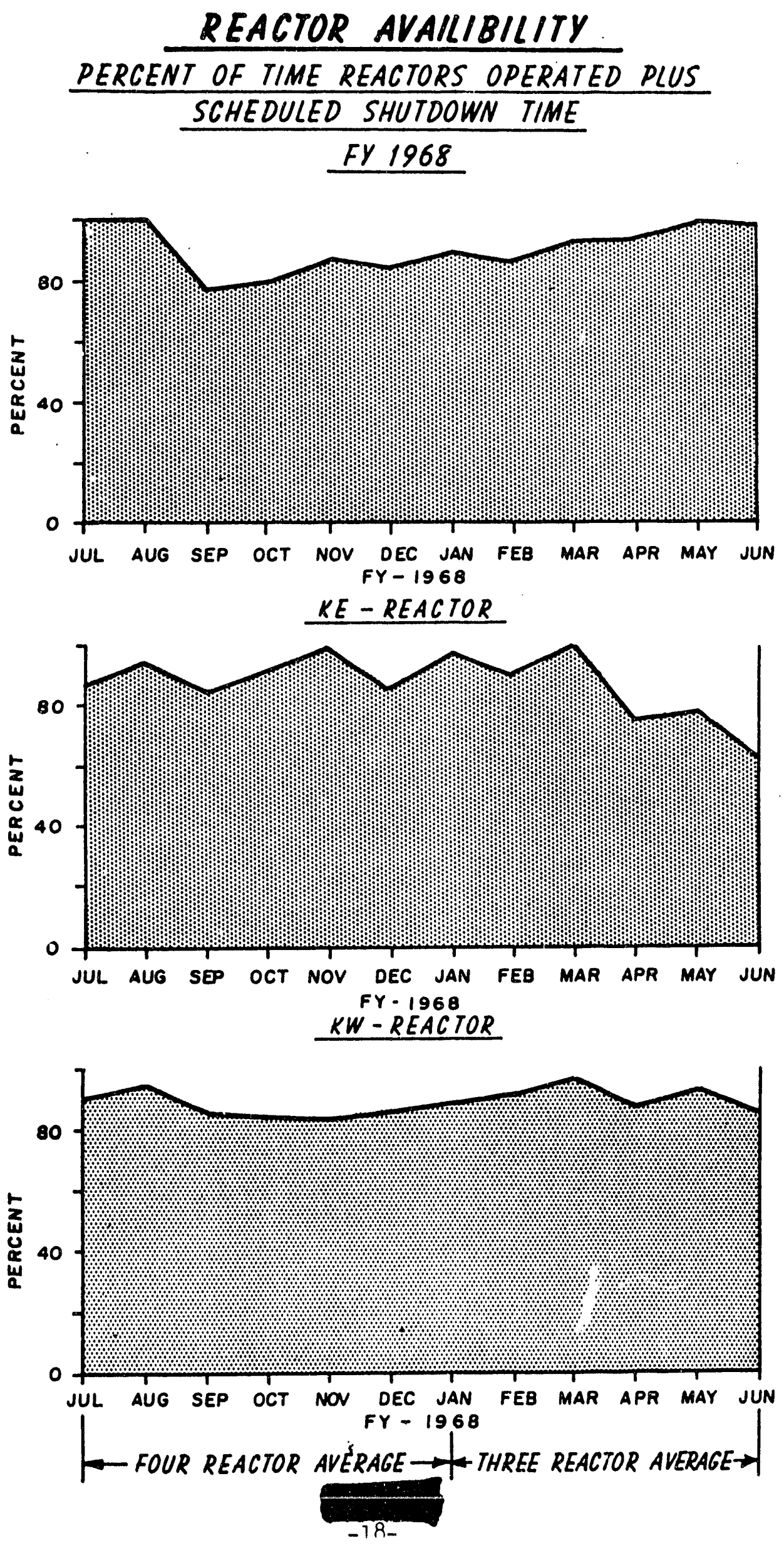

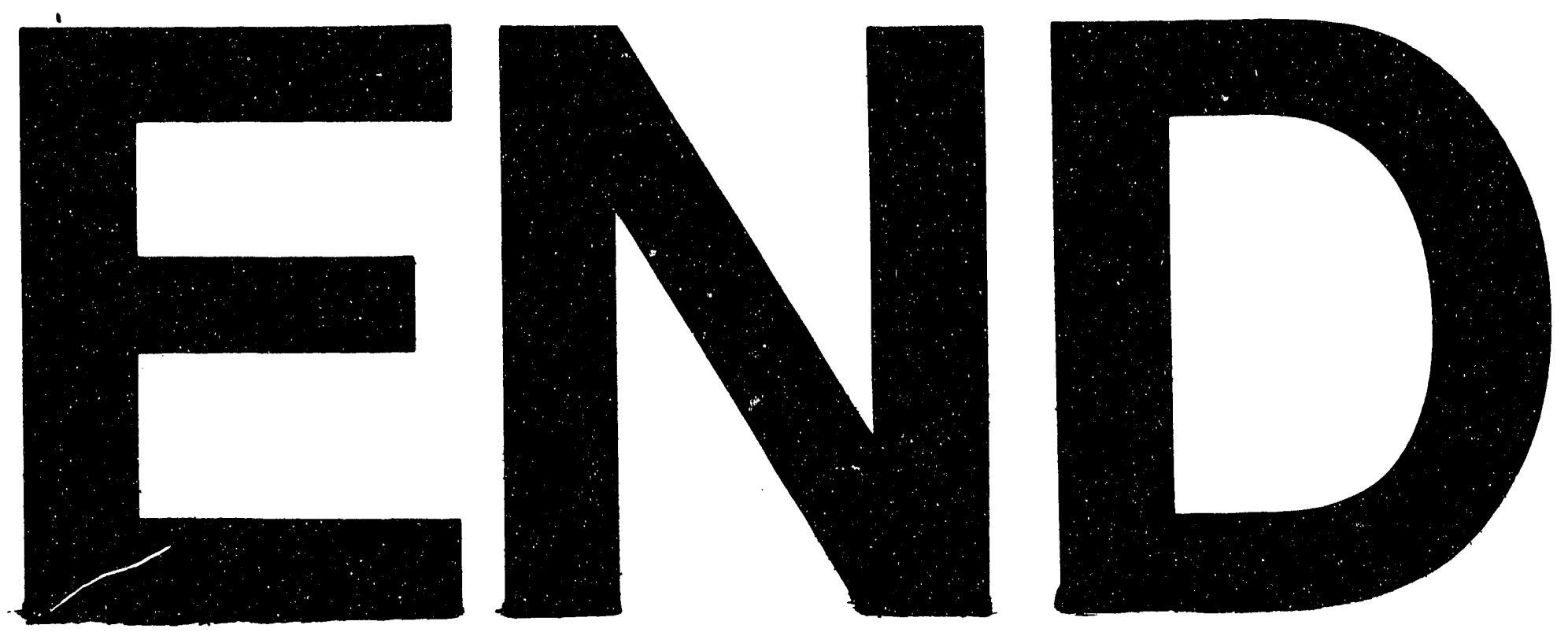

xa

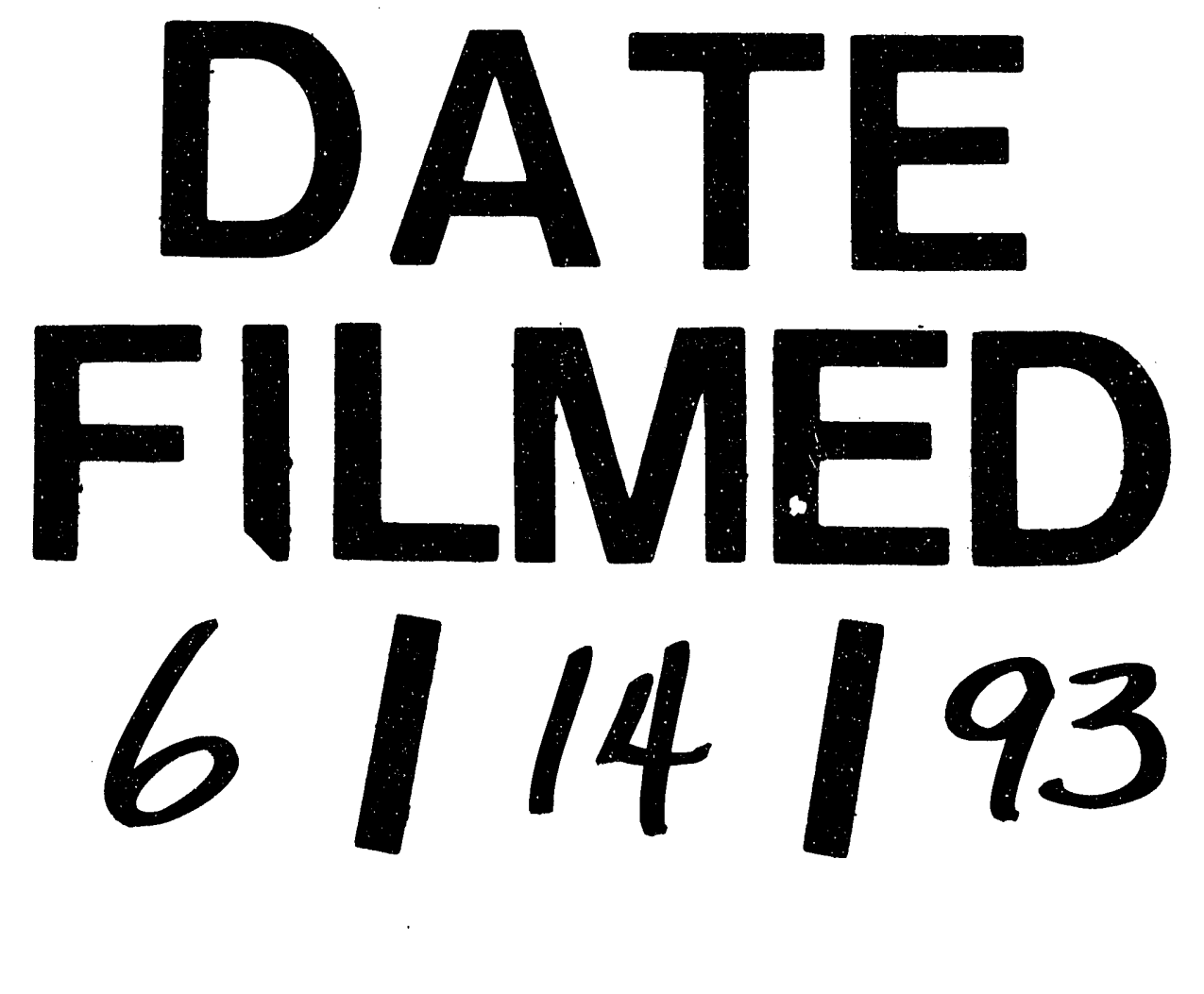


